\title{
AGRO-ECONOMIC PROFITABILITY OF SWEET POTATO CULTIVARS AS A FUNCTION OF THE HARVEST AGE AND TIMES OF CULTIVATION IN THE SEMI-ARID
}

\author{
RENTABILIDADE DE CULTIVARES DE BATATA-DOCE EM FUNÇÃO DA \\ IDADE DE COLHEITA E ÉPOCAS DE CULTIVO NO SEMIÁRIDO
}

\author{
José Ricardo Tavares de ALBUQUERQUE ${ }^{1}$; Manoel Galdino dos SANTOS ${ }^{1}$; \\ Rayanne Maria Paula RIBEIRO' ${ }^{\text {; Hugo FERREIRA }}{ }^{2}$; Ênio Gomes Flôr SOUZA ${ }^{3}$; \\ Hamurábi Anizio LINS'; Aurélio Paes BARROS JÚNIOR ${ }^{4}$; \\ Francisco BEZERRA NETO ${ }^{5}$ \\ 1. Doutorando (a) em Agronomia/Fitotecnia, Universidade Federal Rural do Semi-Árido - UFERSA, Mossoró, RN, Brasil; \\ 2. Graduando em Agronomia - UFERSA, Mossoró, RN, Brasil; 3. Professor, Doutor, Instituto Federal de Alagoas - IFAL, \\ Piranhas, AL, Brasil; 4. Professor, Doutor, Associado I - UFERSA, Mossoró, RN, Brasil; 5. Professor, Doutor, Titular - \\ UFERSA, Mossoró, RN, Brasil. ricardoalbuquerqueagro@gmail.com
}

\begin{abstract}
The objective of this work was to evaluate the profitability of sweet potato cultivars, harvested at different ages and cultivated in different periods (rainy and dry) in the municipality of Mossoró, semi-arid region of Rio Grande do Norte. The experimental design was a randomized complete block design with four replications and treatments arranged in split plots scheme. The plots were composed of three sweet potato cultivars (ESAM 1, Paraná and Mother of Family) and the subplots for five harvest ages $(90,105,120,135$ and 150 days after transplanting DAT). Productivity of commercial roots and production costs was evaluated, as well as the economic indicators: gross income, net income, rate of return and profit margin. Independently of the growing periods, the productivity of commercial roots increased with the later harvest of the crop and differentiated the cultivars. Production costs averaged $\mathrm{R} \$ 6,087.97 \mathrm{ha}^{-1}$ in the rainy season and $\mathrm{R} \$$ $6,181.42 \mathrm{ha}^{-1}$ in the dry period. Labor expenditures were the most impacting of total expenditures. The cultivars ESAM 1 and Paraná presented higher productivities of commercial roots and profitability when cultivated in the rainy season, while Paraná cultivar was superior to the other cultivars in the crop in the dry season. In both growing periods, the harvest age of 150 DAT promoted higher productivities of commercial roots and profitability to sweet potato production.
\end{abstract}

KEYWORDS: Ipomoea batatas L. Economic return. Planting time. Production costs.

\section{INTRODUCTION}

The sweet potato (Ipomoea batatas L.) stands out for the ease of cultivation, rusticity, wide adaptation to different types of soil and climate, high tolerance to drought and low cost of production, being cultivated in practically all Brazilian states. Besides these characteristics, this vegetable has great social importance for being a source of energetic food and rich in carbohydrates, being part of the food habit of the Brazilian (ANDRADE JÚNIOR et al., 2012).

In the national context, in 2016, it was registered a production of 669.45 thousand tons in 49.55 thousand ha, with an average productivity of $14.07 \mathrm{t} \mathrm{ha}^{-1}$ of commercial roots. The State of Rio Grande do Sul was the largest national producer, with a production of 167.85 thousand tons and average productivity of 13.40 $\mathrm{t} \mathrm{ha}^{-1}$. In the Northeast, where the crop has important participation in the economic and social scenarios, the State of Sergipe stands out as the largest producer, with a production of 35.08 thousand tons and an average productivity of $11.50 \mathrm{t} \mathrm{ha}^{-1}$. Rio Grande do Norte is the fifth largest producer in the Northeast Region, with a production of 24.51 thousand tons and an average productivity of $11.43 \mathrm{t} \mathrm{ha}^{-1}$ (IBGE, 2016). In this state, sweet potatoes are grown mainly by family farmers, being an alternative crop for income generation, especially for the low cost of production and for showing a cycle of 90 to 120 days, which provides a regular flow of capital in production (MELO et al., 2009).

In addition to the ease of cultivation, the sweet potato presents a rich germplasm, in which variability is found for several characteristics (peel and pulp coloration, leaf 
Agro-economic profitability...

shape, root insertion type and growth habit, for example), resulting in wide adaptation to different environments and cultivation methods, as well as to serve diverse consumer markets (RITSCHEL; HUAMAN, 2002). Once the variety has been selected, the farmer should be concerned about the point or age of harvest, which is determined by the cultivar and environmental conditions (SMITH; MANTENGO, 1995). The determination of the age of harvest has a great influence on the production and the quality of the aerial part and of the roots, being its management allows to adapt the supply to the demand (QUEIROGA et al., 2007).

Along with the harvest age of sweet potato, there is the growing season, which can be determined by weather elements such as air temperature, photoperiod and solar radiation, which influence growth, development and productivity of tuberous roots (MEDEIROS et al., 1990; VILLORDON et al., 2010). The temperature is described as one of the main variables that influence the formation of tuberous roots, being this formation sensitive to both low and high temperatures (ERPEN et al., 2013).

Thus, the identification of the best cultivars and age of harvest associated with the best growing season can serve as a guide for farmers who produce the sweet potato crop,
ALBUQUERQUE, J. R. T. et al

contributing to the increase of the productive chain, making it more efficient and profitable (ALBUQUERQUE et al., 2016).

In this context, the objective of this work was to evaluate the profitability of sweet potato cultivars, harvested at different ages and cultivated at different periods (rainy and dry) in the municipality of Mossoró, semi-arid region of Rio Grande do Norte.

\section{MATERIAL AND METHODS}

Two experiments were carried out in the field, one in the rainy season (February 10 to July 10, 2015) and another in the dry season (June 29 to November 28, 2015), both in the Experimental Garden of the Universidade Federal Rural do Semi-Árido (UFERSA), municipality of Mossoró-RN, located geographically at $5^{\circ} 11^{\prime} 15$ "S, $37^{\circ} 20^{\prime} 39^{\prime \prime} \mathrm{W}$ and $18 \mathrm{~m}$ altitude. The climate of the region, according to Köppen's classification, is BShw, that is, dry and very hot, with two defined climatic seasons: one dry (June to January) and one rainy (February to May) (CARMO FILHO; OLIVEIRA, 1989). The average meteorological data of the experiment period were obtained from a meteorological station installed at 1.80 $\mathrm{km}$ of the experimental area (Figure 1).

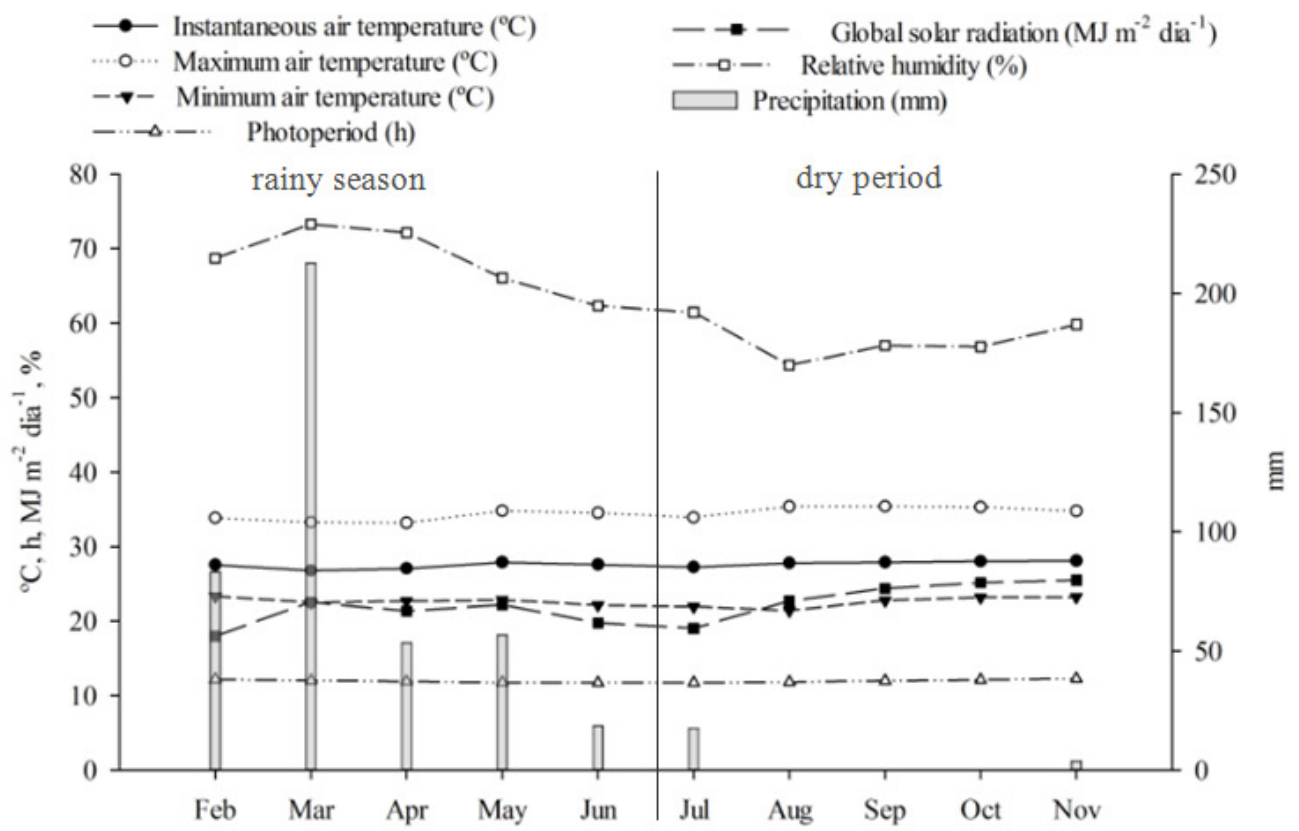

Figure 1. The mean values of instantaneous, maximum and minimum temperatures of air, photoperiod (h), global solar radiation $\left(\mathrm{MJ} \mathrm{m}^{-2}\right.$ day $\left.^{-1}\right)$, relative air humidity $(\%)$ and rainfall $(\mathrm{mm})$ in each cultivation period (wet and dry) of sweet potato in Mossoró, semi-arid region of Rio Grande do Norte, in year 2015. 
The soil of the experimental area was classified as Abrupt Red-Yellow Argisol (SANTOS et al., 2013), sand texture (DONAGEMA et al., 2011), whose chemical analysis (SILVA, 2009), at 0-20 depth cm, before the installation of each experiment, are presented in Table 1.

The experimental design was a randomized complete block design with four replications and treatments arranged in split plots. The plots were composed of three sweet potato cultivars (ESAM 1, Paraná and Mother of Family) and the subplots for five harvest ages $(90,105,120$, 135 and 150 days after transplanting - DAT). The experimental unit was composed of four lines with $3.0 \mathrm{~m}$ length, totaling $12.0 \mathrm{~m}^{2}$ of total area and $4.8 \mathrm{~m}^{2}$ of harvest area.

Table 1. Soil chemical analysis (depth 0 to $20 \mathrm{~cm}$ ) before transplanting sweet potato in the rainy and dry periods of Mossoró, semi-arid region of Rio Grande do Norte.

\begin{tabular}{lclllllllr}
\hline \multirow{2}{*}{ Cultivation periods } & $\mathrm{pH}$ & $\begin{array}{l}\mathrm{CE} \\
\mathrm{dS} \mathrm{m}{ }^{-1}\end{array}$ & $\begin{array}{l}\mathrm{OM} \\
\mathrm{g} \mathrm{kg}^{-1}\end{array}$ & $\begin{array}{l}\mathrm{N} \\
\mathrm{g} \mathrm{kg}^{-1}\end{array}$ & $\begin{array}{l}\mathrm{P} \\
\mathrm{mg} \mathrm{dm}^{-3}\end{array}$ & $\begin{array}{l}\mathrm{K}^{+} \\
--------\mathrm{Cmol}_{\mathrm{c}} \mathrm{dm}^{-3}---------\end{array}$ \\
\hline Rainy & 8.25 & 8.25 & 11.50 & 0.28 & 135.56 & 0.44 & 2.89 & 1.30 & 0.07 \\
Dry & 7.67 & 7.67 & 29.20 & 1.54 & 211.50 & 0.16 & 6.00 & 1.85 & 0.02 \\
\hline *EC = electrical conductivity; $\mathrm{MO}=$ organic matter. $\mathrm{P}, \mathrm{K}^{+}$and $\mathrm{Na}^{+}:$Mehlich $\left(\mathrm{HCl}+\mathrm{H}_{2} \mathrm{SO}_{4}\right) ; \mathrm{Ca}^{2+}, \mathrm{Mg}^{2+}: \mathrm{KCl}$ & $1 \mathrm{M}$.
\end{tabular}

Two months before the installation of each experiment, branches of each cultivar were multiplied. The cultivars have the following characteristics: ESAM 1, spindle roots, pink external film, cortex and white pulp (MURILO et al., 1990); Paraná, rounded roots and orange pulp (MOREIRA et al., 2011); and Mother of Family, irregular long roots, with cream external film and white flesh (ALBUQUERQUE et al., 2015). Soil preparation consisted of plowing and harrowing. Subsequently, beds were erected manually at a height of $30 \mathrm{~cm}$, with the aid of a hoe. The spacing used was $1.00 \mathrm{~m}$ between rows and $0.30 \mathrm{~m}$ between plants. In each hole, two branches with six buds were transplanted each, being three buds were buried, totalizing a population of 80 plants per experimental plot.

In both cultivation periods, fertilization was carried out according to the recommendation for the crop and based on soil analysis, applying $20 \mathrm{~kg} \mathrm{ha}^{-1}$ of $\mathrm{N}, 30 \mathrm{~kg} \mathrm{ha}^{-1}$ of $\mathrm{P}_{2} \mathrm{O}_{5}$ and $20 \mathrm{~kg} \mathrm{ha}^{-1}$ of $\mathrm{K}_{2} \mathrm{O}$, at the time of planting, and $20 \mathrm{~kg} \mathrm{ha}^{-1}$ of $\mathrm{N}, 20 \mathrm{~kg} \mathrm{ha}^{-1}$ of $\mathrm{P}_{2} \mathrm{O}_{5}$ and $20 \mathrm{~kg} \mathrm{ha}^{-1}$ of $\mathrm{K}_{2} \mathrm{O}$, under cover (GOMES; SILVA; COUTINHO, 2008). The sources of nitrogen, phosphorus and potassium were urea, mono-ammonium phosphate (MAP) and potassium chloride, respectively.

The irrigation system was by drip irrigation, with a spacing of $0.30 \mathrm{~m}$ between emitters and an average flow of $1.5 \mathrm{~L} \mathrm{~h}^{-1}$. Irrigations were carried out daily or when necessary, based on estimated crop evapotranspiration $(\mathrm{ETc})(\mathrm{ETc}=\mathrm{ETo} \mathrm{x} \mathrm{Kc})$, based on the FAO (Food and Agriculture Organization of the United Nations) Penman-
Monteith method, where the crop coefficients $(\mathrm{Kc})$ for sweet potato crop were: $\mathrm{Kc}_{\mathrm{ini}}=0.5$; $\mathrm{Kc}_{\text {med }}=1.15$ and $\mathrm{Kcf}_{\text {in }}=0.65$ (ALLEN et al., 2006). Hand weedings were performed when necessary.

At harvest time, productivity of commercial roots (PCR), obtained by weighing the roots of 28 plants of the harvest area of each experimental unit and estimated for $\mathrm{t} \mathrm{ha}^{-1}$, was evaluated (CAVALCANTE et al., 2010). According to Embrapa (1995), roots with a weight greater than $80 \mathrm{~g}$ and without defects, that is, those greenish, cracked or attacked by pests and / or diseases were considered commercial.

Economic indicators were used to evaluate the efficiency of treatments. The production costs of one hectare of sweet potatoes were estimated as a function of to the age of harvest, which were calculated and analyzed at the end of each production process, adapting the methodology proposed by Conab (2010). The gross income (GI) was measured by the value of commercial roots per hectare during the harvest in the rainy $\left(\mathrm{R} \$ 1.10 \mathrm{~kg}^{-1}\right)$ and dry ( $\mathrm{R} \$ 0.90 \mathrm{~kg}^{-1}$ ) periods of 2015 . The US dollar (US \$) was quoted on average at R \$ 3.24 during the year 2015. The net income (NI) was calculated by the difference between the gross income (GI) and the total costs (TC) involved in obtaining of the commercial roots. The rate of return (RR) was determined from the relation between GI and NI, corresponding to the capital obtained for each real applied in the cultivation of sweet potatoes. The profit margin (PM) consisted of the relation between NI and GI, expressed as a percentage. 
Agro-economic profitability...

For each cultivation period (rainy and dry), analyzes of variance of the characteristics were done through the SISVAR application, version 5.6 (FERREIRA, 2011). For the harvesting ages, regression analyzes were performed with the Table Curve 2D program (SYSTAT SOFTWARE, 2002) and the graphs elaborated in Sigma Plot, version 12.0 (SYSTAT SOFTWARE, 2011). The regression equations were chosen based on the following criteria: biological explanation of the phenomenon, simplicity of the equation and test
ALBUQUERQUE, J. R. T. et al

of the parameters of the equation by Student's $t$ test, at $5 \%$ probability.

\section{RESULTS AND DISCUSSION}

\section{Rainy period}

According to the analysis of variance, it was observed that there was a significant interaction between the harvest ages and the sweet potato cultivars for all characteristics evaluated (Table 2).

Table 2. Summary of variance analysis (F values) for productivity commercial roots (PCR), gross income (GI) and rate of return (RR) in the production of sweet potato cultivars at different harvest ages in the rainy season of Mossoró, semi-arid region of Rio Grande do Norte.

\begin{tabular}{|c|c|c|c|c|}
\hline \multirow[b]{2}{*}{ Sources of Variation } & \multirow[b]{2}{*}{$\mathrm{df}$} & \multicolumn{3}{|l|}{ F values } \\
\hline & & PCR & GI & $\mathrm{RR}$ \\
\hline Blocks & 3 & $0.08^{\mathrm{ns}}$ & $1.14^{\mathrm{ns}}$ & $1.10^{\mathrm{ns}}$ \\
\hline Harvest ages (A) & 4 & $156.33 * *$ & $2.702 .23 * *$ & $1.924 .71 * *$ \\
\hline Cultivars (C) & 2 & $587.10 * *$ & $367.20 * *$ & $379.13 * *$ \\
\hline $\mathrm{A} \times \mathrm{C}$ & 8 & $6.15 * *$ & $9.83 * *$ & $11.32 * *$ \\
\hline $\mathrm{CV} 1(\%)$ & & 7.60 & 2.67 & 2.79 \\
\hline CV $2(\%)$ & & 5.67 & 5.07 & 5.10 \\
\hline Overall mean & & 5.88 & 6.468 .97 & 1.04 \\
\hline
\end{tabular}

ns; ** and ": not significant, significant at $1 \%$ and $5 \%$ probability, by the F test, respectively; df: degrees of freedom; CV: coefficient of variation.

For the productivity of commercial roots, the highest values were reached when the harvest was performed at 150 DAT for all cultivars (Figure 2A): ESAM 1 (8.76 $\left.\mathrm{t} \mathrm{ha}^{-1}\right)$, Paraná (9.19 t ha-1) and Mother of Family (7.47 $\left.\mathrm{t} \mathrm{ha}^{-1}\right)$. These positive results are probably due to the greater accumulation of photo assimilated in the tuberous roots, due to the longer culture time in the field (ALBUQUERQUE et al., 2016).

The source-drain relationship may also have been determinant in this aspect, because generally, at the end of the sweet potato cycle, there is a reduction of the aerial part and a greater production of tuberous roots. According to Conceição et al. (2004), the production of the tuberous root is a function of the potential of the source (aerial part) in accumulating nutrients for later translocation towards the drain formed by the roots.

Evaluating three sweet potato cultivars as a function of harvest ages in the Mossoró-RN conditions, Queiroga et al. (2007) also obtained an increase in the productivity of commercial roots up to 155 DAT, corroborating with the results found in this research, since it emphasizes that the increase in the period of permanence of the plants in the field benefits the productivity of this vegetable.

The cultivars ESAM 1 and Paraná presented similar productivities of commercial roots, reaching 8.93 and $9.19 \mathrm{t} \mathrm{ha}^{-1}$ at 150 DAT (Figure 2A), respectively, values superior to the Mother of Family (7.55 t ha-1). The sweet potato is a perennial crop of continuous tuberization under favorable conditions, so that the longer duration of the tuberization to harvesting start allows longer time for the accumulation of photos assimilated in the roots (ERPEN et al., 2013; ALBUQUERQUE et al. ., 2016).

The price paid for sweet potatoes in the rainy season (February-May) was $\mathrm{R} \$ 1.10 \mathrm{~kg}^{-1}$, based on this, the gross income results had similar behavior to that observed for productivity of commercial roots, that is, for all cultivars evaluated, the greater permanence of the crop in the field promoted increases in gross income values (Figure 2B). This permanence of the crop in the field entails greater investment in the cost of the crop, for example, increases the costs with irrigation. However, it was observed that there was also an increase in the productivity of commercial roots with harvest delay, showing 
that this relation was advantageous, that is, the value invested was compensated (Figure 2A).

A

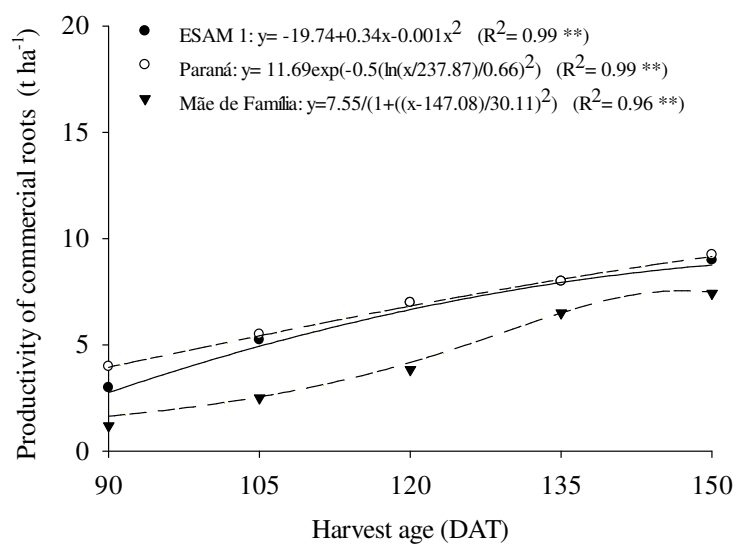

$\mathrm{C}$

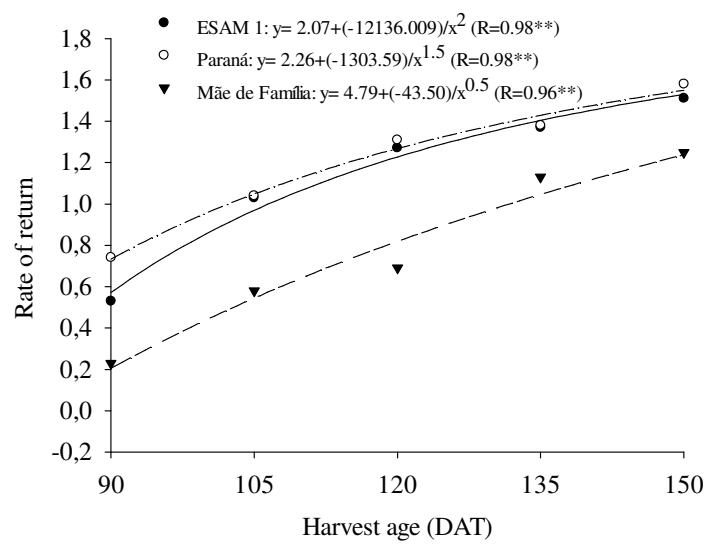

B

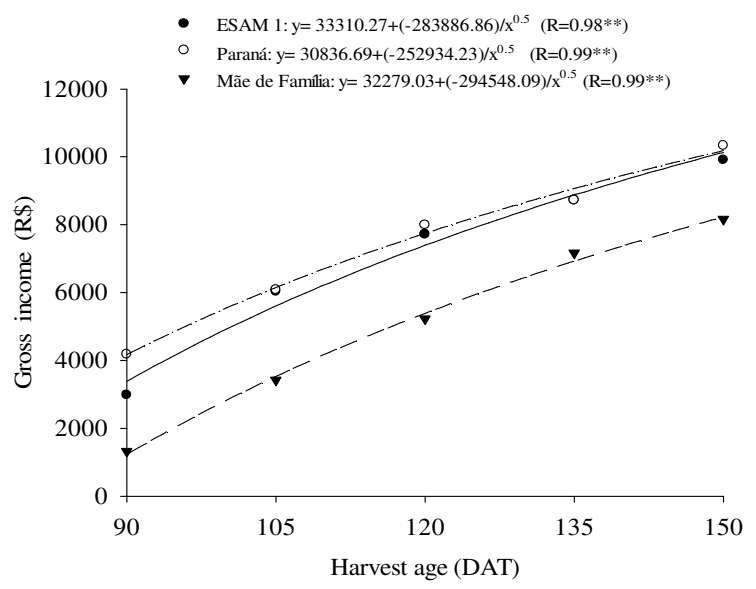

Figure 2. Productivity of commercial roots (A), gross income (B) and rate of return (C) of the interaction of the harvest ages as a function of sweet potato cultivars produced in the rainy season of Mossoró, semi-arid region of Rio Grande do Norte.

The cultivars ESAM $1\left(\mathrm{R} \$ 9,914.90 \mathrm{ha}^{-1}\right)$ and Paraná $\left(\mathrm{R} \$ 10,334.10 \mathrm{ha}^{-1}\right)$ obtained similar gross incomes and higher than the Mother of Family when harvested between 105 and 150 DAT (Figure 2B). At 150 DAT, the ESAM 1 cultivar presented a gross income of 10,131.01ha 1, Paraná 10,184.69 ha- ${ }^{-1}$ and Mother of Family $8,229.28 \mathrm{ha}^{-1}$ (Figure 2B). Gross income is directly associated with commercial productivity, in which the increase in the age of harvest benefited the gross income for the cultivars studied.

Table 3 shows the sum of variable, fixed and operational costs in the production of one hectare of sweet potatoes as a function of harvest ages $(90,105,120,135$ and 150 DAT) in the rainy season of Mossoró-RN, being verified the following values, respectively: $\mathrm{R} \$ 5,617.48 \mathrm{ha}^{-1}$; $\mathrm{R} \$ 5,855.35 \mathrm{ha}^{-1} ; \mathrm{R} \$ 6,094.81 \mathrm{ha}^{-1} ; \mathrm{R} \$ 6,332.90$ $\mathrm{ha}^{-1}$ and $\mathrm{R} \$ 6,539.32 \mathrm{ha}^{-1}$.

Expenditure on crop cultivation costs are related to the costs of renting machinery for plowing, erection and dismantling of the irrigation system, electric power, ridging, cutting, distribution and burial of branches, irrigation, weedings, heap, harvesting and root classification of sweet potatoes, in addition to fertilizers. 
Agro-economic profitability...

ALBUQUERQUE, J. R. T. et al

Table 3. Average values of variable, fixed, operational and total costs in the production of one hectare of sweet potatoes as a function of harvest ages and growing seasons in Mossoró, semi-arid region of Rio Grande do Norte.

\begin{tabular}{|c|c|c|c|c|c|}
\hline \multirow[b]{2}{*}{ Discrimination } & \multirow[b]{2}{*}{ Unity } & \multicolumn{2}{|c|}{ Rainy period } & \multicolumn{2}{|c|}{ Dry period } \\
\hline & & Amount & $\mathrm{R} \$$ & Amount & $\mathrm{R} \$$ \\
\hline \multicolumn{6}{|l|}{ I - Expenditure on crop cultivation costs } \\
\hline \multicolumn{6}{|l|}{1 - Machine rental } \\
\hline Tractor with disk harrow & $\mathrm{h}$ & 1.50 & 165.00 & 1.50 & 165.00 \\
\hline \multicolumn{6}{|l|}{2 - Labor } \\
\hline Mounting the irrigation system & daily & 4.00 & 140.00 & 4.00 & 140.00 \\
\hline Ridging & daily & 14.00 & 490.00 & 14.00 & 490.00 \\
\hline Stem cutting & daily & 5.00 & 175.00 & 5.00 & 175.00 \\
\hline Distribution and burial of stems & daily & 13.00 & 455.00 & 13.00 & 455.00 \\
\hline Irrigation and / or fertirrigation & $\mathrm{h}$ & 52.00 & 227.50 & 60.00 & 262.50 \\
\hline Weedings and heap & daily & 20.00 & 700.00 & 20.00 & 700.00 \\
\hline Manual harvest/classification & daily & 42.00 & $1,470.00$ & 42.00 & $1,470.00$ \\
\hline Dismantling of the irrigation system & daily & 4.00 & 140.00 & 4.00 & 140.00 \\
\hline \multicolumn{6}{|l|}{3 - Fertilizers } \\
\hline Urea $(45 \% \mathrm{~N})-40 \mathrm{~kg} \mathrm{ha}^{-1} \mathrm{~N}$ & $\mathrm{~kg}$ & 63.42 & 62.15 & 63.42 & 68.49 \\
\hline $\operatorname{MAP}\left(48 \% \mathrm{P}_{2} \mathrm{O}_{5}\right.$ e $\left.11 \% \mathrm{~N}\right)-50 \mathrm{~kg} \mathrm{ha}^{-1} \mathrm{P}_{2} \mathrm{O}_{5}$ & $\mathrm{~kg}$ & 104.17 & 118.75 & 104.17 & 129.17 \\
\hline $\mathrm{KCl}\left(60 \% \mathrm{~K}_{2} \mathrm{O}\right)-40 \mathrm{~kg} \mathrm{ha}^{-1} \mathrm{~K}_{2} \mathrm{O}$ & $\mathrm{kg}$ & 66.67 & 68.00 & 66.67 & 78.67 \\
\hline \multicolumn{6}{|l|}{4 - Others } \\
\hline Soil analysis & unity & 1.00 & 35.00 & 1.00 & 35.00 \\
\hline Electricity for irrigation & $\mathrm{kWh}$ & 140.32 & 53.32 & 210.34 & 79.93 \\
\hline Subtotal (A) & & & $4,299.73$ & & $4,388.76$ \\
\hline \multicolumn{6}{|l|}{ II - Other expenses } \\
\hline \multirow{3}{*}{\multicolumn{2}{|c|}{$\begin{array}{l}5 \text { - Administrative expenses ( } 3 \% \text { of the cost of the cro } \\
6 \text { - Technical assistance ( } 2 \% \text { of the cost of the crop) } \\
7 \text { - Rural territorial tax }\left(\mathrm{R} \$ 10.00 \text { year }^{-1}\right)\end{array}$}} & & 128.99 & & 131.66 \\
\hline & & & 85.99 & & 87.78 \\
\hline & & & 2.47 & & 2.47 \\
\hline \multicolumn{2}{|l|}{ Subtotal (B) } & & 217.45 & & 221.90 \\
\hline \multicolumn{6}{|l|}{ III - Financial expenses } \\
\hline \multicolumn{2}{|l|}{8 - Interest on financing $\left(7.49 \%\right.$ year $\left.^{-1}\right)$} & & 79.41 & & 81.45 \\
\hline \multicolumn{2}{|l|}{ Subtotal (C) } & & 79.41 & & 81.45 \\
\hline \multicolumn{2}{|l|}{ Variable cost $(\mathrm{A}+\mathrm{B}+\mathrm{C}=\mathrm{D})$} & & $4,596.59$ & & $4,691.72$ \\
\hline \multicolumn{6}{|l|}{ IV - Depreciation } \\
\hline \multicolumn{2}{|l|}{9 - Depreciation of facilities * } & & 545.37 & & 545.37 \\
\hline \multicolumn{2}{|l|}{ Subtotal (E) } & & 545.37 & & 545.37 \\
\hline \multicolumn{6}{|l|}{ V - Other fixed costs } \\
\hline \multicolumn{2}{|l|}{ Subtotal (F) } & & 25.66 & & 25.66 \\
\hline \multicolumn{2}{|l|}{ Fixed cost $(E+F=G)$} & & 571.03 & & 571.03 \\
\hline \multicolumn{2}{|l|}{ Operational cost $(\mathrm{D}+\mathrm{G}=\mathrm{H})$} & & $5,167.62$ & & $5,262.75$ \\
\hline \multicolumn{2}{|l|}{$\begin{array}{l}\text { VI - Income from factors } \\
11 \text { - Remuneration on fixed capital }\left(6 \% \text { year }^{-1}\right) \\
12 \text { - Rent }\left(\mathrm{R} \$ 1.200,00 \mathrm{ha}^{-1} \text { year }^{-1}\right)\end{array}$} & & $\begin{array}{l}153.97 \\
295.89\end{array}$ & & $\begin{array}{l}153.97 \\
295.89\end{array}$ \\
\hline
\end{tabular}




\begin{tabular}{lll}
\hline Subtotal $(\mathrm{I})$ & 449.86 & 449.86 \\
\hline Total cost $(\mathrm{H}+\mathrm{I}=\mathrm{J})-\mathbf{9 0}$ days & $\mathbf{5 , 6 1 7 . 4 8}$ & $\mathbf{5 , 7 1 2 . 6 1}$ \\
\hline Total cost $-\mathbf{1 0 5}$ days & $\mathbf{5 , 8 5 5 . 3 5}$ & $\mathbf{5 , 9 4 8 . 7 7}$ \\
\hline Total cost $-\mathbf{1 2 0}$ days & $\mathbf{6 , 0 9 4 . 8 1}$ & $\mathbf{6 , 1 8 6 . 6 6}$ \\
\hline Total cost $-\mathbf{1 3 5}$ days & $\mathbf{6 , 3 3 2 . 9 0}$ & $\mathbf{6 , 4 2 5 . 5 6}$ \\
\hline Total cost $-\mathbf{1 5 0}$ days & $\mathbf{6 , 5 3 9 . 3 2}$ & $\mathbf{6 , 6 3 3 . 4 8}$ \\
\hline
\end{tabular}

$* 10,000 \mathrm{~m}$ of low-density polyethylene drip tapes with emitters spaced $0.30 \mathrm{~m}$ and nominal diameter $16 \mathrm{~mm}$ (useful life $=2$ years, well new value $=\mathrm{R} \$ 0.37 \mathrm{~m}^{-1}$ ); pipes and connections in PVC (lifespan $=15$ years, value of the new good $=\mathrm{R} \$$ $4,735.00$ residual value $=\mathrm{R} \$ 947.00)$.

In general, labor costs were the most impacting in the cost of the crop (Table 3). In the rainy season, labor averaged $62.78 \%$ of the total costs of the crop. If the labor force is employed by the family itself, this expense would be transformed into net income for the activity, thus generating income and contributing to the fixation of the man in the field.

Labor with manual harvesting and sorting was responsible for the highest cost within the cost $(33,45 \%$ of the cost or $\mathrm{R} \$$ $1,470.00 \mathrm{ha}^{-1}$ ) (Table 3). It is fundamental that the farmer seeks to carry it out to reduce such expenditure. Melo et al. (2009), when estimating and analyzing the cost of production and the profitability of the sweet potato crop in the irrigated perimeters of the State of Sergipe, also stated that the cost of labor was the main cost of the crop, being manual harvesting and classification the activities with the highest disbursement.

Irrigation was responsible for the increase in labor costs due to crop failure $(\mathrm{R} \$$ $227.50 \mathrm{ha}^{-1}$ at $90 \mathrm{DAT}$ for R $\$ 376.25 \mathrm{ha}^{-1}$ at 150 DAT). This aspect emphasizes the great importance of culture, as an activity that generates employment in the rural environment and that occupies, throughout the year, the man in the field, through the use of his labor (MELO et al., 2009).

In terms of total costs, fertilizer costs averaged $1.08 \% ; 1.96 \%$ and $1.14 \%$ for nitrogen, phosphorus and potassium sources, respectively, in the rainy season (Table 3 ). The price of urea was R $\$ 0.98 \mathrm{~kg}^{-1}$, MAP of R\$ 1.14 $\mathrm{kg}^{-1}$ and potassium chloride of $\mathrm{R} \$ 1.02 \mathrm{~kg}^{-1}$. Sweet potatoes have little nutritional requirement and are generally grown depending on the natural fertility of the soil or the previous fertilizer residue, so that the cost of fertilizers had little participation in the total costs. According to Oliveira et al. (2006), sweet potato because they have a very branched root system becomes more efficient in the absorption of nutrients, making the crop have a high capacity to exploit soil fertility.

The total costs also burdened with the depreciation of the irrigation system, since the useful life of the drip tapes is only two years, and it is essential that the farmer save on average $\mathrm{R} \$$ $616.44 \mathrm{ha}^{-1}$ in the rainy season in order to accumulate the amount necessary to restore this material at the appropriate time, avoiding problems such as the clogging of emitters, whose consequence is the low efficiency of application of water and fertilizers. The opportunity cost related to the rental of the property was also significant, as it corresponded, on average, to $4.89 \%$ of the total costs (Table 3 ).

For the variables net income and profit margin it was not possible to perform analysis of variance due to the lack of normality of the data, being evaluated only the average values. From the difference between gross income and total costs, we have the net income of sweet potato production, which reached maximum average values when it was associated with the highest harvest age (Table 4). At 150 DAT, the cultivars ESAM 1, Paraná and Mother of Family provided net incomes of R \$3,375.58 ha' $; \mathrm{R} \$ 3,794.78 \mathrm{ha}^{-1}$ and $\mathrm{R} \$ 1,626.58 \mathrm{ha}^{-1}$, respectively. At the age of 90 DAT, net incomes were negative for all cultivars, indicating financial loss for the activity under the conditions of the present experiment. For ESAM 1 and Paraná, net income became positive from the harvest at $105 \mathrm{DAT}$, while the Mother of Family was profitable only at 135 and 150 DAT.

There was an increase in the rate of return with the increase in sweet potato growing time (Figure 2C), being of the order of $184.90 \%$ for ESAM 1, $113.51 \%$ for Paraná and $443.47 \%$ for Mother of Family between harvest at 90 and 150 DAT. The rate of return consists of equations that associate production costs, gross income and profit, thus being variables that can assist the producer in making the decision on the need for 
Agro-economic profitability...

investment capital, as well as allowing him to envisage the possibility of economic return.

Table 4. Mean values of net income (NI) and profit margin (PM) of sweet potato cultivars as a function of harvest ages in the rainy season of Mossoró, semi-arid region of Rio Grande do Norte.

\begin{tabular}{|c|c|c|c|c|c|}
\hline \multirow{3}{*}{ Cultivars } & \multicolumn{5}{|c|}{ Harvest ages (days after transplanting) } \\
\hline & 90 & 105 & 120 & 135 & 150 \\
\hline & \multicolumn{5}{|c|}{ Net income $\left(\mathrm{R} \$ \mathrm{ha}^{-1}\right)$} \\
\hline ESAM 1 & $-2,626.41$ & 182.10 & $1,643.40$ & $2,396.23$ & $3,375.58$ \\
\hline Paraná & $-1,435.20$ & 230.74 & $1,915.02$ & $2,396.80$ & $3,794.78$ \\
\hline \multirow[t]{2}{*}{ Mother of Family } & $-4,293.48$ & $-2,429.54$ & $-1,847.90$ & 833.51 & $1,626.58$ \\
\hline & \multicolumn{5}{|c|}{ Profit margin $(\%)$} \\
\hline ESAM 1 & -88.08 & 2.44 & 21.26 & 27.41 & 34.03 \\
\hline Paraná & -34.69 & 3.66 & 23.93 & 27.44 & 36.68 \\
\hline Mother of Family & -328.67 & -71.83 & -43.87 & 11.56 & 19.60 \\
\hline
\end{tabular}

In the same way as for productivity of commercial roots and gross income, the cultivars ESAM 1 (1.03 to 1.51$)$ and Paraná (1.04 to 1.58$)$ had rates of return that were equal to each other and larger than (0.58 to 1.25$)$ between the harvests of 105 and 150 DAT, demonstrating the greatest potential of economic return of these two cultivars. The cultivars ESAM 1 and Mother of Family present white pulp color, while the Paraná orange pulp. These characteristics are directly associated with the preference of the consumer market, on which it depends on each region. In the Northeast, sweet potato cultivars with cream and white pulp color are well accepted in the market. However, orange pulp cultivars are still not common in the local market, even if they stand out as a source of carotenoids and vitamin $\mathrm{C}$, and can act as antioxidants (PADMAJA, 2009).
Regarding the profit margin, the results showed a positive profitability from the 105 DAT for the cultivars ESAM 1 and Paraná (Table 4). In this case, the profit margin ranged between 2.44 and $34.03 \%$ for ESAM 1 and 3.66 and $36.68 \%$ for Paraná. The cultivar Mother of Family had a negative profit margin of 90 to 120 DAT, however, from 135 DAT showed profitability of $11.56 \%$, evolving to $19.60 \%$ at 150 DAT.

\section{Dry period}

From the analysis of variance, it was observed that there was a significant interaction between the harvest ages and the sweet potato cultivars for all characteristics evaluated (Table $5)$.

Table 5. Summary of analysis of variance (F values) for productivity of commercial roots (PCR), gross income (GI), net income (NI), rate of return (RR) and profit margin (PM) in the production of sweet potato cultivars at different harvest ages in the dry period of Mossoró, semiarid of Rio Grande do Norte.

\begin{tabular}{lllllll}
\hline Sources of Variation & \multicolumn{2}{l}{$\mathrm{F}$ values } \\
\cline { 2 - 7 } & df & PCR & GI & NI & RR & PM \\
\hline Blocks & 3 & $1,00^{\text {ns }}$ & $0,31^{\text {ns }}$ & $0,31^{\text {ns }}$ & $0,43^{\text {ns }}$ & $0,18^{\text {ns }}$ \\
Harvest ages (A) & 4 & $35,111.52^{* *}$ & $62,743.52^{* *}$ & $53,505.60^{* *}$ & $52,172.15^{* *}$ & $125,731.52^{* *}$ \\
Cultivars (C) & 2 & $61,761.05^{* *}$ & $12,438.65^{* *}$ & $12,438.38^{* *}$ & $11,530.24^{* *}$ & $91,027.74^{* *}$ \\
A x C & 8 & $1,837.90^{* *}$ & $2,166.48^{* *}$ & $2,166.43^{* *}$ & $2,096.17^{* *}$ & $84,507.05^{* *}$ \\
CV 1 $(\%)$ & & 0.40 & 0.72 & 2.42 & 0.74 & -3.36 \\
CV 2 (\%) & 0.72 & 0.67 & 2.24 & 0.70 & -3.07 \\
Overall mean & 9.77 & $8,793.62$ & $2,612.20$ & 1.39 & -60.19 \\
\hline
\end{tabular}

ns; ${ }^{* *}$ and *: not significant, significant at $1 \%$ and $5 \%$ probability, by the $\mathrm{F}$ test, respectively; df: degrees of freedom; CV: coefficient of variation.

After the initiation of tuberization, productivity depends on the ability of the aerial part to produce assimilates and translocate them to the roots (SOMASUNDARAM; MITHRA, 2008). Based on this, generally, with the harvest delay, an increase in the productivity of 
Agro-economic profitability...

commercial roots takes place. Consequently, high levels of solar radiation positively affect root productivity, since this variable is the source of energy for photosynthesis (ALBUQUERQUE et al., 2016).

Evaluating five sweet potato cultivars and two harvesting dates (150 and 200 days after planting) in northern Minas Gerais between summer and autumn, Resende (2000), showed an increase in productivity of all cultivars at 200 DAT, also attributing the

ALBUQUERQUE, J. R. T. et al

A
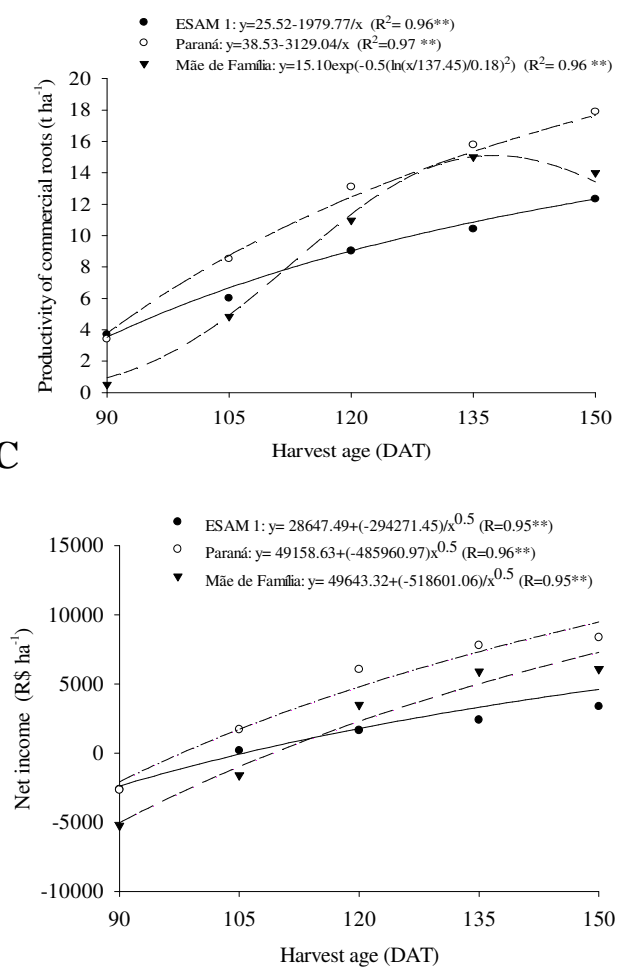

$\mathbf{E}$

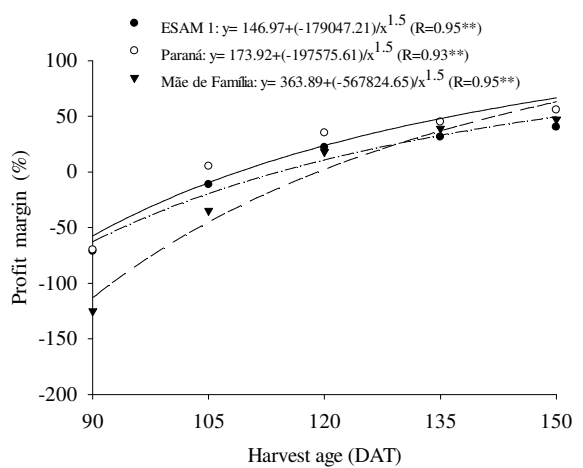

results to the longer period of permanence of the culture in the field.

In the dry period of sweet potato cultivation, the highest values of productivity of commercial roots (PCR) were found at 150 DAT for the Paraná and Mother of Family cultivars (Figure 3A), while the cultivar Mother of Family showed decrease in PCR from 135 DAT (Figure 3A). Regardless of harvest age, Parana cultivar presented the highest PCR, reaching $17.67 \mathrm{t} \mathrm{ha}^{-1}$ at 150 DAT (Figure $3 \mathrm{~A}$ ).

B

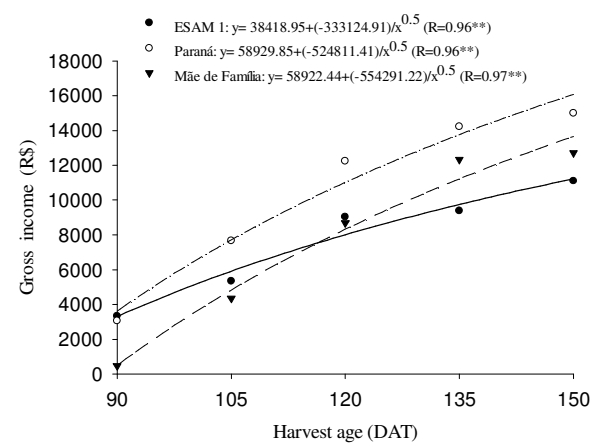

D

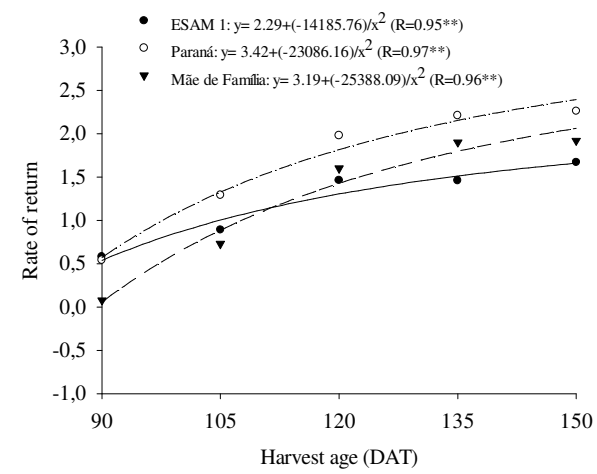

Figure 3. Productivity of commercial roots (A), gross income (B), net income (C), rate of return (D) and profit margin (E) of the interaction of harvest ages as a function of sweet potato cultivars produced in the period dry state of Mossoró, semi-arid region of Rio Grande do Norte.

The results of gross income in the dry season presented statistical behavior similar to that observed for the productivity of commercial roots, since this variable reflects the product of the price paid by sweet potatoes and their productive yield (Figure 3B). Among the cultivars, Paraná was the one that obtained the highest gross income from the 105 DAT, 
surpassing the other cultivars, reaching $R \$$ 15,000.00 at 150 DAT (Figure 3B).

The root kilogram price was reduced from $\mathrm{R} \$ 1.10$ (rainy season) to $\mathrm{R} \$ 0.90$ (dry period), mainly due to the increase in the cultivation of this vegetable in the producing regions of the State of Rio Grande do Norte and the entrance of the product from surrounding states, such as Sergipe, Ceará and Paraíba, major producers of this tuberous root in the Northeast.

Table 3 shows the sum of variable, fixed and operational costs in the production of sweet potatoes in the dry period $(\mathrm{R} \$ 5,262.75)$ as a function of the harvest ages $(90,105,120$, 135 and 150 DAT ), being the following values verified, respectively: $\mathrm{R} \$ 5,712,61 ; \mathrm{R} \$$ 5,948.77; $\mathrm{R} \$ 6,166.66 ; \mathrm{R} \$ 6,425.56$ and $\mathrm{R} \$$ $6,633.48$.

According to Table 3, the most important expenses for the cost of sweet potato crop in the dry period were related to labor, in which on average it contributed with a $63.46 \%$ share in the total costs of the crop. The increase in labor costs is directly related to the greater expense of planting (ridging, distribution, and burial of branches) and harvesting/manual sorting. An alternative to reducing the costs involved in harvesting / grading would be adherence to community work, where the exchange of kindness is still widely used in the field. The cultivation of sweet potatoes is directly linked with the fixation of the man in the field, generating employment and income.

Regarding fertilization, fertilizer disbursement averaged $4.87 \%$ of total costs (Table 3). The disbursement with fertilizers was low, because the sweet potato crop presented as a rustic plant, not demanding in nutrients. There are reports from growers who consider sweet potatoes prefer poor soil, "in fact, there is a remarkable ability of the roots of this plant to use less useful forms of the available nutrients, such as phosphorus, for example, due to an association with mycorrhizae (PRADO; CECÍLIO FILHO, 2016).

The depreciation of the irrigation system also cost the total costs, since it was considered a two-year useful life for the drip tapes (CUNHA et al., 2012), and it is fundamental that the farmer save $\mathrm{R} \$ 616.44 \mathrm{ha}^{-1}$ in the dry period in order to transform into capital the amount necessary to restore this material in the appropriate period, avoiding problems such as clogging of drippers, for example, resulting in low efficiency of application of water and nutrients in the crop. The opportunity cost related to the rental of the property was also significant, since it corresponded to R $\$ 295.89 \mathrm{ha}^{-1}$ at $90 \mathrm{DAT}$ and $\mathrm{R} \$ 493.15 \mathrm{ha}^{-1}$ at 150 DAT (Table 3). The renounced opportunity cost is related to the value that the producer could have saved if he had not invested in the production of sweet potatoes, but this investment is offset by the amount invested.

In the dry cultivation period, the net income of sweet potato roots increased as a function of harvest ages for all cultivars studied (Figure 3C), reaching the maximum values of $\mathrm{R}$ \$ 4,466.52; R \$ 6,079.02 and $\mathrm{R} \$$ 8,366.52 for the cultivars ESAM 1, Paraná and Mother of Family, respectively, at 150 DAT. When the roots were harvested at 90 and 105 DAT, negative results were found for the ESAM 1 and Family Mother cultivars, proving that harvesting was not feasible before 120 DAT (Table 3).

The production of sweet potatoes at different harvest ages provided a higher rate of return on investment with postponing crop harvest (Figure 3D). The cultivar Paraná, obtained the highest values from the 105 DAT, reaching the maximum value of 2.39 reais per return invested at 150 DAT (Figure 3D).

Regarding the profitability index, statistical behavior similar to the rate of return was observed, that is, the later the harvest, the higher the results were observed (Figure $3 \mathrm{E}$ ). The profit margin varied between -62.72 and $37.52 \%$ for ESAM 1 cultivar and between -57.47 and $55.75 \%$ for Paraná cultivar (Figure 3E). The cultivar Mother of Family showed a negative profit margin between 90 and 105 DAT, however, from the 120 DAT presented positive indices (-125.47-54.8047.84\%) (Figure 3E).

From the analysis of the productive and economic indicators, it is considered that the irrigated cultivation of the sweet potato was viable in both periods of culture, being indicated later harvests, that is, from 120 DAT.

\section{CONCLUSIONS}

The cultivars ESAM 1 and Paraná presented higher productivities of commercial roots and profitability when cultivated in the rainy season of Mossoró-RN, while the Paraná was superior to the other cultivars in the dry season. 
Agro-economic profitability...

In both cultivation periods, the harvest age of 150 days after transplanting promoted
ALBUQUERQUE, J. R. T. et al

higher productivities of commercial roots and profitability to sweet potato yield.

RESUMO: Este trabalho teve como objetivo avaliar a rentabilidade de cultivares de batatadoce, colhidas em diferentes idades e cultivadas em períodos distintos (chuvoso e seco) no município de Mossoró, semiárido do Rio Grande do Norte. O delineamento experimental foi em blocos ao acaso, com quatro repetições e tratamentos arranjados em parcelas subdivididas, sendo as parcelas formadas por três cultivares de batata-doce (ESAM 1, Paraná e Mãe de Família) e as subparcelas por cinco idades de colheita $(90,105,120,135$ e 150 dias após o transplantio - DAT). Avaliaram-se produtividade de raízes comerciais e custos de produção, assim como os indicadores econômicos: renda bruta, renda líquida, taxa de retorno e índice de lucratividade. Independentemente dos períodos de cultivo, a produtividade de raízes comerciais aumentou com a colheita mais tardia da cultura e diferenciou as cultivares. Os custos de produção foram em média da ordem de $\mathrm{R} \$ 6.087,97 \mathrm{ha}^{-1}$ no período chuvoso e $\mathrm{R} \$ 6.181,42 \mathrm{ha}^{-1}$ no período seco. As despesas com mão de obra foram as mais impactantes nas despesas totais. As cultivares ESAM 1 e Paraná apresentaram maiores produtividades de raízes comerciais e lucratividades quando cultivadas no período chuvoso, enquanto a Paraná foi superior as demais cultivares no cultivo na época seca. Em ambas as épocas de cultivo, a idade de colheita de 150 DAT promoveu maiores produtividades de raízes comerciais e rentabilidade à produção de batata-doce.

PALAVRAS-CHAVES: Ipomoea batatas L. Custos de produção. Época de plantio. Retorno econômico.

\section{REFERENCES}

ALBUQUERQUE, J. R. T.; RIBEIRO, R. M. P.; PEREIRA, L. A. F.; BARROS JÚNIOR, A. P.; SILVEIRA, L. M.; SANTOS, M. G.; SOUZA, A. R. E.; LINS, H. A.; BEZERRA NETO, F. Sweet potato cultivars grown and harvested at diferente times in semiarid Brazil. African Journal of Agricultural Research, Lagos, v. 11, n. 46, p. 4810-4818, nov. 2016.

https://doi.org/10.5897/AJAR2016.11761

ALBUQUERQUE, J. R. T.; SANTOS, M. G.; RIBEIRO, R. M. P.; PEREIRA, L. A. F.; OLIVEIRA, F. S.; SOUZA, A. R. E.; SILVEIRA, L. M.; BARROS JÚNIOR, A. P. Caracterização morfoagronômica de raízes de acessos de batata-doce em coleção didática da UFERSA. In: SIMPÓSIO DE RECURSOS GENÉTICOS PARA A AMÉRICA LATINA E O CARIBE, 10., 2015, Bento Gonçaves. Anais... Bento Gonçalves: SBRG, 2015.

ALLEN, R. G.; PEREIRA, L. S.; RAES, D.; SMITH, M. Crop evapotranspiration: guidelines for computing crop water requirements. Rome: FAO, 2006. 298 p. (FAO - Irrigation and Drainage Paper, 56).

ANDRADE JÚNIOR, V. C.; VIANA, D. J. S; PINTO, N. A. V. D.; RIBEIRO, K. G.; PEREIRA, R. C.; AZEVEDO, A. M.; ANDRADE, P. C. R. Características produtivas e qualitativas de ramas e raízes de batata-doce. Horticultura Brasileira, Vitória da Conquista, v. 30, n. 4, p. 584-589, oct/dec. 2012. https://doi.org/10.1590/S0102-05362012000400004

CARMO FILHO, F.; OLIVEIRA, O. F. Mossoró: um município do semi-árido nordestino "Características climáticas e aspectos florísticos". Mossoró: ESAM, 1989. p. 62.

CAVALCANTE, M.; FERREIRA, P. V.; PAIXÃO, S. L.; COSTA, J. G.; PEREIRA, R. G.; MADALENA, J. A. Desempenho agronômico, dissimilaridade genética e seleção de genitores de batata doce para hibridização. Revista Brasileira de Ciências Agrárias, Recife, v. 5, n. 4, p. 485-490, oct/dec. 2010. https://doi.org/10.5239/agraria.v5i4.816 
CONCEIÇÃO, M. K.; LOPES, N. F.; FORTES, G. R. L. Partição de matéria seca entre órgão de batata-doce (Ipomoea batatas (L.) Lam), cultivares Abóbora e Da Costa. Revista Brasileira de Agrociências, Pelotas, v. 10, n. 3, p. 313-316, july/sept. 2004. https://doi.org/ 10.18539/CAST.V10I3.964

CUNHA, J. L. O.; PORDEUS, R. V.; SILVA JÚNIOR, M. J. S.; AZEVEDO, C. A. V. Impactos econômicos da depreciação de sistemas de irrigação por gotejamento nos custos de produção agrícola. Enciclopédia Biosfera, Goiânia, v. 8, n. 15, p.1008-1020, oct/nov. 2012.

Custos de produção agrícola: a metodologia da CONAB. Brasília: CONAB, 2010. 41160 p.

DONAGEMA, G. K.; CAMPOS, D. V. B.; CALDERANO, S. B.; TEIXEIRA, W. G.; VIANA, J. H. M. Manual de métodos de análises de solos. 2. ed. Rio de Janeiro: Embrapa Solos, dec. 2011, p. 4349.

EMPRESA BRASILEIRA DE PESQUISA AGROPECUÁRIA. Centro Nacional de Pesquisa de Hortaliças. A Cultura da batata-doce. Brasília: EMBRAPA-SPI. 95p. (Coleção Plantar; 30). Centro Nacional de Pesquisa de Hortaliças. Cultivo da batata-doce (Ipomoea batatas (L.) Lam). produções técnicas do CNP Hortaliças. $3^{a}$ ed. Brasília: EMBRAPA. 1995.

ERPEN, L.; STRECK, N. A.; UHLMANN, L. O.; FREITAS, C. P. O.; ANDRIOLO, J. L. Tuberização e produtividade de batata-doce em função de datas de plantio em clima subtropical. Bragantia, Campinas, v. 72, n. 4, p.396-402, july/oct. 2013. https://dx.doi.org/10.1590/brag.2013.050

FERREIRA, D. F. Sisvar: a computer statistical analysis system. Ciência e Agrotecnologia, Lavras, v. 35, n. 6, p. 1039-1042, nov/dec. 2011. https://dx.doi.org/10.1590/S1413-70542011000600001

GOMES, R. V.; SILVA, M. C. L. Recomendações de adubação para o Estado de Pernambuco: $2^{\text {a }}$ aproximação. 3. ed. Revisada. Recife: Instituto Agronômico de Pernambuco-IPA, 2008. 212 p.

IBGE. Instituto Brasileiro de Geografia e Estatística. Diretoria de Pesquisas, Coordenação de Agropecuária, Produção Agrícola Municipal 2016. Available at: <http://www.ibge.gov.br>. Acessed on: Jan 13, 2018.

MEDEIROS, J. G.; PEREIRA, W.; MIRANDA, J. E. C. Análise de crescimento em duas cultivares de batata-doce (Ipomoea batatas (L.) Lam). Revista Brasileira de Fisiologia Vegetal, Londrina, v. 2, n. 2, p. 23-29, 1990.

MELO, A. S.; COSTA, B. C.; BRITO, M. E. B.; AGUIAR NETTO, A. O.; VIÉGAS, P. R. A. Custo e rentabilidade na produção de batata-doce nos perímetros irrigados de Itabaiana, Sergipe. Pesquisa Agropecuária Tropical, Goiânia, v. 39, n. 2, p. 119-123, abr/jun. 2009.

https://ri.ufs.br/jspui/handle/riufs/1258

MOREIRA, J. N.; QUEIROGA, R. C. F.; SOUSA JÚNIOR, A. J. L.; SANTOS, M. A. Caracteres morfofisiológicos e produtivos de cultivares de batata-doce, em Mossoró, RN. Revista Verde, Pombal, v. 6, p. 161-167, 2011.

MOTA, J. H.; RESENDE, G. M.; YURI, J. E. SOUZA, R. J. Nutrição e adubação da cultura da batata-doce. In: PRADO, R. M.; CECÍLIO FILHO, A. B. (Ed). Nutrição e adubação de hortaliças Jaboticabal: FCAV/CAPES, 2016. 543 p.

MURILO, D. V.; PEDROSA, J. F.; NUNES, C. L. F. ESAM 1, 2 e 3: Novas cultivares de batata-doce para a região semi-árida. Horticultura Brasileira, Brasília, v. 8, n. 2, p. 32-33, 1990. 
OLIVEIRA, A. P.; SILVA, J. E. L.; PEREIRA, W. E.; BARBOSA, L. J. N.; Oliveira, A. N. P. Características produtivas da batata-doce em função de doses de $\mathrm{P}_{2} \mathrm{O}_{5}$, de espaçamentos e de sistemas de plantio. Ciência e Agrotecnologia, Lavras, v. 30, n. 4, p. 611-617, jul/ago. 2006.

https://dx.doi.org/10.1590/S1413-70542006000400003

PADMAJA, G. Uses and nutritional data of sweet potato. Biomedical and Life Sciences, Lancaster, p.189-234, 2009. https://doi:10.1007/978-1-4020-9475-0_11

QUEIROGA, R. C. F.; SANTOS, M. A.; MENEZES, M. A.; VIEIRA, C. P. G.; SILVA, M. C. Fisiologia e produção de cultivares de batata-doce em função da época de colheita. Horticultura Brasileira, Brasília, v. 25, n. 3, p. 371-374, july/sept. 2007. http://dx.doi.org/10.1590/S010205362007000300010

RESENDE, G. M. Características produtivas de cultivares de batata-doce em duas épocas de colheita, em Porteirinha-MG. Horticultura Brasileira, Brasília, v. 18, n. 1, p. 68-71, mar. 2000. https://dx.doi.org/10.1590/S0102-05362000000100016

RITSCHEL, P. S.; HUAMÁN, Z. Variabilidade morfológica da coleção de germoplasma de batatadoce da Embrapa-Centro Nacional de Pesquisas de Hortaliças. Pesquisa Agropecuária Brasileira, Brasília, v. 37, n. 4, p. 485-492, abr. 2002. https://dx.doi.org/10.1590/S0100-204X2002000400009

SANTOS, H. G. et al. Sistema Brasileiro de Classificação de Solos. 3. ed. rev. ampl. Brasília: Embrapa, 2013. 353 p.

SILVA, F. C. (Ed.). Manual de análises químicas de solos, plantas e fertilizantes. 2. ed. rev. ampl. Brasília: Embrapa Informação Tecnológica, 2009. 627 p.

SMITH, W. E. J. M; MANTENGO, L. O. Farmer's cultural practices and their effects on pest control in sweet potato in south Nyanza, Kenia. International Journal of Pest Management, Londres, v. 41, p. 2-7, nov. 1995. https://doi.org/10.1080/09670879509371912

SOMASUNDARAM, K.; MITHRA, V. S. Madhuram: A simulation model for sweet potato growth. World Journal of Agricultural Sciences, Dubai, v. 4, n. 2, p. 241-254, 2008.

SYSTAT SOFTWARE. SigmaPlot for Windows Version 12.0. San Jose: Systat Software Inc., 2011.

SYSTAT SOFTWARE. Table curve 2D and 3D. San Jose: MMIV Systat Software 209 Inc., 2002.

VILLORDON, A.; SOLIS, J.; LABONDE, D.; CLARK, C. Development of a prototype bayesian network model representing the relationship between fresh market yield and some agroclimatic variables known to influence storage root initiation in sweet potato. HortScience, v. 45, n. 8, p. 11671177, aug. 2010. https://doi.org/10.21273/HORTSCI.45.8.1167 